\title{
The metabolism of maltitol in the rat
}

\author{
BY REBECCA LIAN-LOH AND GORDON G. BIRCH \\ National College of Food Technology, University of Reading, St Georges Avenue, \\ Weybridge, Surrey KT13 ODE \\ AND MARIE E. COATES \\ National Institute for Research in Dairying, Shinfield, Reading RG2 9AT
}

(Received 1 February 1982 - Accepted 21 June 1982)

1. Conventional (CV) rats were given a single oral dose of 1 or $2 \mathrm{~g}$ maltitol. Urine and faeces were collected during the following $24 \mathrm{~h}$ and their contents of maltitol and sorbitol were measured.

2. Very little of either substance appeared in the faeces but appreciable amounts of sorbitol found in the urine indicated that the maltitol had been hydrolysed.

3. Excretion of maltitol and sorbitol was compared in germ-free and $\mathrm{CV}$ rats given an oral dose of $2 \mathrm{~g} \mathrm{maltitol}$. Significantly less of both substances was recovered in the faeces of CV rats, but urinary excretion was similar in both environments.

4. Maltitol injected intravenously gave rise to only traces of sorbitol in the excreta. A dose of $250 \mathrm{mg}$ was cleared almost completely from the circulation within $1 \mathrm{~h}$.

5. It is concluded that maltitol is hydrolysed by animal tissues, either in the gut lumen before absorption or in the gut wall during absorption. Maltitol and sorbitol are also degraded by gut bacteria, mostly in sites distal to the main absorptive area. The contribution to the host's nutrition would depend on the extent to which the end-products of fermentation are absorbed from the colon.

Maltitol (4-O- $\alpha$-D-glucopyranosyl-D-sorbitol) is a sweetening agent believed to have low cariogenic activity (Frostell, 1963) and is thus a potentially desirable ingredient of human foods. Although it is only slowly hydrolysed to glucose and sorbitol by intestinal maltase (Dahlqvist \& Telenius, 1965), in our preliminary studies considerable amounts of sorbitol were found in the urine of rats given diets containing maltitol. Sorbitol was also detected in the urine of human subjects after oral doses of maltitol (Kearsley \& Lian-Loh, 1982). This could arise through breakdown of absorbed maltitol in the tissues or through microbial action in the gut with subsequent absorption of the products. The experiments now described were done to investigate the metabolism of maltitol in the rat and the contribution of the gut microflora to its digestion.

\section{EXPERIMENT AL \\ Test materials}

Maltitol was supplied as a solution in water $(700 \mathrm{~g} / \mathrm{kg})$. For the experiment with germ-free rats a solution containing $0.25 \mathrm{~g}$ maltitol $/ \mathrm{ml}$ was sterilized by autoclaving at $115^{\circ}$ for $10 \mathrm{~min}$. Subsequent analysis showed that no loss or alteration had occurred during the treatment. The other source of maltitol was Lycasin, a commercial product containing $520 \mathrm{~g}$ maltitol $/ \mathrm{kg}$ and a mixture of higher polyols susceptible to hydrolysis to glucose and maltitol. Both materials were provided by Roquette (UK) Ltd, Tunbridge Wells.

\section{Animals and dosage}

Lister hooded rats bred in the National Institute for Research in Dairying colony and aged between 6 and 10 weeks were used. They were maintained on a commercial diet (Expanded Rodent Cubes; Labsure, Wimborne, Dorset). Germ-free (GF) rats were bred and reared 
in plastic isolators on the same diet, sterilized by gamma-radiation at $5 \mathrm{Mrad}$. They were checked regularly for freedom from microbial contaminants as described by Fuller (1968). Where direct comparisons were to be made between GF and conventional (CV) animals half of each GF litter was removed from the isolator at 6 weeks of age into a room in which $\mathrm{CV}$ rats were already present. To encourage the rapid establishment of an appropriate indigenous gut microflora they were housed in cages that had been soiled by $\mathrm{CV}$ rats. At least 2 weeks elapsed before they were used for experiment. CV rats were housed in cages similar to those of their CF counterparts and environmental conditions of lighting and temperature were matched to those inside the isolators.

In Expts 1-3 the rats were given a single oral dose of the test material by stomach tube, in $4 \mathrm{ml}$ water, after an overnight fast. They were lightly anaesthetized while the dose was administered, either with diethyl ether (Expts 1 and 2) or Halothane (Expt 3). They were then immediately placed in glass metabolism jars (Rolls et al. 1976) in which urine could be collected on filter paper lining the base of the jar. Water and the cubed diet (which contained no sorbitol or maltitol) were provided. After $24 \mathrm{~h}$ the animals were removed and, where necessary, blood was obtained by cardiac puncture. Faecal pellets were picked off the filter paper with forceps, diet crumbs were discarded and the filter paper transferred to another container. The glass jar was rinsed with distilled water and the rinsings added to the filter paper. All samples were stored at $-20^{\circ}$ until analysed.

In Expt 4 fully-fed rats were used so that their digestive processes would be active. They were given an intravenous injection of maltitol via the tail vein. Half were placed in metabolism jars and treated as described in the previous experiments. The remainder were retained for $1 \mathrm{~h}$ while samples of blood were taken before dosing and at $15 \mathrm{~min}$ intervals from the tip of the tail.

\section{Analytical procedures}

Sorbitol and maltitol and glucose were determined by gas-liquid chromatography after silylation with a mixture of hexamethyldisilazane (HMDS)-trifluoroacetic acid (TFA) in pyridine $(9: 1, w / w)$, using perseitol (Sigma Chemical Company, Poole, Dorset) as an internal standard (Brobst \& Lott, 1966).

\section{Preparation of samples}

Blood. Blood samples were prepared according to Somogyi (1930) with slight modifications. A sample of $0.1 \mathrm{ml}$ whole blood was laked into $1.7 \mathrm{ml}$ distilled water and $0.1 \mathrm{ml}$ zinc sulphate solution $(100 \mathrm{~g} / \mathrm{l})$ was added. After thorough mixing $0.1 \mathrm{ml} 0.5 \mathrm{M}$-sodium hydroxide was added dropwise with continuous shaking. The mixture was allowed to stand for $5 \mathrm{~min}$, then centrifuged at $1500 \mathrm{~g}$ for $5 \mathrm{~min}$. To $1.0 \mathrm{ml}$ supernatant fraction an appropriate amount of perseitol was added as an internal standard and the sample was freeze-dried. The dried material was taken up into a mixture of $1.0 \mathrm{ml}$ pyridine, $0.9 \mathrm{ml} \mathrm{HMDS}$ and $0.1 \mathrm{ml}$ TFA, shaken vigorously for $5 \mathrm{~min}$ and allowed to stand for $10 \mathrm{~min}$ before being introduced on to the column.

Urine. Urine was extracted from the 'cut-up' filter paper with $50 \mathrm{ml}$ distilled water. The extract was centrifuged at $2000 \mathrm{~g}$ for $20 \mathrm{~min}$ and $1.0 \mathrm{ml}$ portions of the supernatant fraction containing a known amount of perseitol were freeze-dried and silyated as previously described.

Faeces. An approximately $5 \mathrm{~g}$ sample was accurately weighed and homogenized in $20 \mathrm{ml}$ absolute methanol in an Ultra-turrax homogenizer (Scientific Instrument Centre, London). The vessel was washed out with methanol $(800 \mathrm{ml} / \mathrm{l})$ and the combined homogenate and washings made up to $50 \mathrm{ml}$ with methanol. The mixture was centrifuged at $2000 \mathrm{~g}$ for 20 $\mathrm{min}$ and $1.0 \mathrm{ml}$ portions of the supernatant fraction with an appropriate amount of perseitol were freeze-dried and silylated. 
Table 1. Amounts ( $\mathrm{mg}$ ) of sorbitol and maltitol excreted by rats in $24 \mathrm{~h}$ after a single oral dose of maltitol or its equivalent as Lycasin $\dagger$

\begin{tabular}{|c|c|c|c|c|c|c|c|c|c|c|c|}
\hline \multirow{3}{*}{$\begin{array}{l}\text { Dose } \\
(\mathrm{g})\end{array}$} & \multirow{3}{*}{$\begin{array}{l}\text { No. of } \\
\text { rats }\end{array}$} & \multirow{3}{*}{$\begin{array}{c}\text { Source of } \\
\text { maltitol }\end{array}$} & \multicolumn{4}{|c|}{ Urine } & \multicolumn{4}{|c|}{ Faeces } & \multirow{3}{*}{$\begin{array}{c}\text { Proportion } \\
\text { of dose } \\
\text { excreted } \ddagger\end{array}$} \\
\hline & & & \multicolumn{2}{|c|}{ Sorbitol } & \multicolumn{2}{|c|}{ Maltitol } & \multicolumn{2}{|c|}{ Sorbitol } & \multicolumn{2}{|c|}{ Maltitol } & \\
\hline & & & Mean & $\mathrm{SE}$ & Mean & $\mathrm{SE}$ & Mean & SE & Mean & SE & \\
\hline 2 & 3 & Lycasin & $433^{*}$ & 90 & $322^{*}$ & 40 & 22 & 7 & 32 & 13 & 0.61 \\
\hline 2 & 3 & Maltitol & 144 & 20 & 180 & 20 & 15 & 2 & 2 & 0 & $0 \cdot 24$ \\
\hline 1 & 6 & Lycasin & $56^{*}$ & 5 & $180^{*}$ & 14 & 8 & 2 & 2 & 0 & $0 \cdot 15$ \\
\hline 1 & 6 & Maltitol & 5 & 3 & 4 & 2 & 8 & 3 & 0.6 & $0 \cdot 3$ & 0.03 \\
\hline
\end{tabular}

* Significantly different from the value for pure maltitol $(P<0.05)$.

$\uparrow$ Provided by Roquette (UK) Lid, Tunbridge Wells.

$\ddagger$ I mg sorbitol $\equiv 1.89 \mathrm{mg}$ maltitol.

\section{Design of experiments}

The first two experiments were designed to investigate the fate of maltitol during $24 \mathrm{~h}$ after a single dose of the pure substances or its equivalent as Lycasin. In Expt 1 groups of three female rats, weighing between 150 and $200 \mathrm{~g}$, were given $2 \mathrm{~g}$ maltitol. In Expt 2 groups of six male rats weighing approximately $250 \mathrm{~g}$ received a dose of $1 \mathrm{~g}$ maltitol. Maltitol and sorbitol were measured in the $24 \mathrm{~h}$ collections of urine and faeces.

In Expt 3 the influence of the gut microflora on maltitol metabolism was studied. Groups of three male and three female GF rats weighing approximately $200 \mathrm{~g}$, and their CV counterparts, were given a dose of pure maltitol. Maltitol and sorbitol were measured as before in the $24 \mathrm{~h}$ collections of excreta.

Expt 4 was designed to examine the contribution of the tissues to maltitol catabolism. A dose of $0.25 \mathrm{~g}$ pure maltitol was given intravenously to seven $\mathrm{CV}$ rats, four males weighing 200-250 $\mathrm{g}$ and three females weighing $150-200 \mathrm{~g}$. Two of each sex were kept in metabolism jars for $24 \mathrm{~h}$ collection of urine and faeces. Blood samples were taken before injection and at $15 \mathrm{~min}$ intervals up to $1 \mathrm{~h}$ from the remaining rats, which were then discarded.

\section{Statistical treatment}

Student's $t$ test was used to assess the significance of differences between results for maltitol and Lycasin in Expts 1 and 2, and for GF and CV animals in Expt 3.

\section{RESULTS}

The results of the first two experiments are summarized in Table 1. When pure maltitol was given, only one-quarter of the $2 \mathrm{~g}$ dose and hardly any of the $1 \mathrm{~g}$ dose were recovered in the excreta. Significantly more sorbitol and maltitol were excreted when the dose was given as Lycasin. Most of the excretory products appeared in the urine, with only traces surviving in the faeces.

In Expt 3 (Table 2) the animals were heavier than those in Expt 1, and very little of the $2 \mathrm{~g}$ dose was excreted by the $\mathrm{CV}$ rats. The corresponding GF rats excreted the equivalent of more than one-quarter of the dose, the difference being mainly due to significantly greater amounts of maltitol and, more particularly, sorbitol in the faeces, compared with their CV counterparts.

In Expt 4 no maltitol and only traces of sorbitol were detected in the faeces of the four rats given an intravenous injection of pure maltitol. The corresponding urinary values were maltitol $209.4 \pm 8.1 \mathrm{mg}$; sorbitol $7.4 \pm 2.9 \mathrm{mg}$. The concentrations of maltitol and glucose 
Table 2. Amounts ( $m g$ ) of sorbitol and maltitol excreted by six germ-free (GF) and six conventional $(C V)$ rats in $24 \mathrm{~h}$ after a single oral dose of $2 \mathrm{~g}$ maltitol

\begin{tabular}{|c|c|c|c|c|c|c|c|c|c|}
\hline \multirow{3}{*}{$\begin{array}{l}\text { Status of } \\
\text { rats }\end{array}$} & \multicolumn{4}{|c|}{ Urine } & \multicolumn{4}{|c|}{ Faeces } & \multirow{3}{*}{$\begin{array}{l}\text { Proportion } \\
\text { of dose } \\
\text { excreted } \dagger\end{array}$} \\
\hline & \multicolumn{2}{|c|}{ Sorbitol } & \multicolumn{2}{|c|}{ Maltitol } & \multicolumn{2}{|c|}{ Sorbitol } & \multicolumn{2}{|c|}{ Maltitol } & \\
\hline & Mean & SE & Mean & $\mathrm{SE}$ & Mean & SE & Mean & $\mathbf{S E}$ & \\
\hline $\mathrm{CV}$ & $46 \cdot 6$ & $29 \cdot 5$ & $10 \cdot 0$ & $2 \cdot 7$ & $18 \cdot 9^{* * *}$ & 11.9 & $0.08^{*}$ & 0.08 & 0.06 \\
\hline GF & $86 \cdot 5$ & $24 \cdot 5$ & $13 \cdot 1$ & $5 \cdot 0$ & $211 \cdot 6$ & $24 \cdot 0$ & $10 \cdot 4$ & $9 \cdot 2$ & $0 \cdot 29$ \\
\hline
\end{tabular}

Significantly different from GF value: ${ }^{*} P<0.05,{ }^{* * *} P<0.001$.

$\dagger 1 \mathrm{mg}$ sorbitol $\equiv 1.89 \mathrm{mg}$ maltitol.

Table 3. Concentration ( $\mathrm{mg} / \mathrm{l}$ ) of maltitol and glucose in the blood of three rats given an intravenous injection of $250 \mathrm{~g}$ maltitol

\begin{tabular}{|c|c|c|c|c|c|}
\hline \multirow{2}{*}{$\begin{array}{l}\text { Time after } \\
\text { dose (min) }\end{array}$} & \multicolumn{3}{|c|}{ Maltitol } & \multicolumn{2}{|c|}{ Glucose } \\
\hline & Mean & Range & $\begin{array}{l}\text { Estimated } \\
\text { total amount } \\
\text { circulating* } \\
\text { (mg) }\end{array}$ & Mean & Range \\
\hline 0 & 0 & & & 97 & $87-107$ \\
\hline 15 & 253 & $101-552$ & $42 \cdot 5$ & 77 & $42-98$ \\
\hline 30 & 85 & 66-106 & $17 \cdot 3$ & 102 & $69-154$ \\
\hline 45 & 63 & $62-65$ & $13 \cdot 4$ & 99 & $71-122$ \\
\hline 60 & 45 & $25-55$ & $9 \cdot 0$ & 107 & $70-143$ \\
\hline
\end{tabular}

* Assuming $0.09 \mathrm{ml}$ blood $/ \mathrm{g}$ body-weight.

in the blood of three rats injected similarly are shown in Table 3 . The range of values for maltitol concentration at $15 \mathrm{~min}$ after the injection was wide, the highest concentration being recorded for the lightest rat. An estimate of the total circulating maltitol, assuming $0.09 \mathrm{ml} \mathrm{blood} / \mathrm{g}$ body-weight, shows that a large proportion of the injected dose had disappeared within $15 \mathrm{~min}$ and very little was left at the end of $1 \mathrm{~h}$. Blood glucose concentrations were very variable but there was no indication of an increase after the maltitol injection. No sorbitol was detectable in blood samples after any time interval.

\section{DISCUSSION}

The results of these studies suggest that young adult conventional rats are able to metabolize at least $1 \mathrm{~g}$ maltitol in $24 \mathrm{~h}$. When pure maltitol was given orally very little of the dose was excreted unchanged. Only traces were found in the faeces and the amounts appearing in the urine were related to the weights of the rats. After a $2 \mathrm{~g}$ dose the lighter animals used in Expt 1 excreted $180 \mathrm{mg}$ maltitol whereas the heavier rats in Expt 3 excreted only $10 \mathrm{mg}$ maltitol. On both occasions appreciable quantities of sorbitol were found in the urine, indicating that maltitol has been hydrolysed either in the gut, with subsequent absorption of the end-products, or in the animal tissues after absorption. Very little maltitol or sorbitol was detected in the urine or faeces after the $1 \mathrm{~g}$ dose. When maltitol was administered in the form of Lycasin and pattern of excretion was similar but the quantities of both maltitol and sorbitol in the urine was significantly higher. Lycasin contains maltitol and an almost equal amount of higher polyols, and it seems likely that the higher excretion values were due to hydrolysis of some of the polyols to maltitol. 
The results of the experiment with GF rats indicate that the gut microflora has a considerable capacity for hydrolysing maltitol. The excretory products from GF rats represented almost one-third of the dose given, whereas those from $\mathrm{CV}$ rats contained the equivalent of less than one-tenth. The difference was largely due to a much greater recovery of sorbitol in the faeces of the GF animals, which implies that in CV circumstances sorbitol released from maltitol by the action of either bacterial or intestinal enzymes is efficiently degraded by gut bacteria. In view of the appreciable amount of sorbitol excreted by the GF animals it must be assumed that the host's enzymes played a major part in the hydrolysis of maltitol. Significantly more maltitol was excreted in the faeces of GF compared with CV rats, although the amount was much smaller than that of sorbitol. This indicates that at least some bacterial degradation of maltitol per se occurs.

In contrast to the findings after an oral dose, maltitol injected intravenously gave rise to very little sorbitol, in the urine or faeces. A dose of $250 \mathrm{mg}$ maltitol was virtually cleared from the blood within $1 \mathrm{~h}$ and at most the equivalent of only approximately $30 \mathrm{mg}$ was recovered as sorbitol in the excreta after $24 \mathrm{~h}$. Blood glucose concentrations were very variable, presumably because food intake was not controlled, but there was no evidence of a rise in blood glucose after injection of maltitol. It appears therefore that little or no metabolism of maltitol had occurred in the tissues.

The findings with GF rats permit the conclusion that maltitol is hydrolysed to sorbitol in the host's tissues. Since more of an intravenous dose was rapidly excreted unchanged, it seems likely that hydrolysis is effected by gastric or intestinal enzymes before absorption. Comparison between GF and $\mathrm{CV}$ rats shows that intestinal micro-organisms are capable of degrading maltitol and, to a greater extent, sorbitol. For example, approximately one-quarter of a $2 \mathrm{~g}$ oral dose was microbially degraded in the $\mathrm{CV}$ rats. Earlier workers (Rennhard \& Bianchine, 1976) investigated the metabolic fate of isotopically-labelled maltitol given orally to $\mathrm{CV}$ rats and dogs and human subjects. From the rapid appearance of the label in the expired carbon dioxide Rennhard \& Bianchine (1976) suggested that hydrolysis of maltitol occurred in the stomach. However, they concluded that the principal route of utilization was by fermentation by intestinal bacteria to volatile fatty acids. In the experiments reported here the urinary contents of sorbitol and maltitol were very nearly as high in the $\mathrm{CV}$ as in the GF animals, implying that microbial degradation had taken place in the lower gut, beyond the main site of absorption. It is, however, possible that end-products of fermentation such as volatile fatty acids might be absorbed from the colon and contribute to the host's energy requirement.

The authors are grateful to Dr M. W. Kearsley for helpful discussions, to Miss M. Tyler and $\mathrm{Mr} \mathrm{J}$. P. Fordham for care of the experimental animals and to Roquette Freres, Lestrem, France for supporting the work and supplying maltitol and Lycasin.

\section{REFERENCES}

Brobst, K. M. \& Lott, C. E. (1966). Cereal Chem. 43, 35.

Dahlqvist, A. \& Telenius, U. (1965). Acta physiol. scand. 63, 156.

Frostell, G. (1963). Sverig. Tendlak. Forb. Tian 55, 529.

Fuller, R. (1968). In The Germ-free Animal in Research, p. 37 [M. E. Coates, editor]. London and New York: Academic Press.

Kearsley, M. W. \& Lian-Loh, R. (1982). In Nutritive Sweeteners, p. 195 [G. G. Birch and K. J. Parker, editors]. London: Applied Science.

Rennhard, H. H. \& Bianchine, J. R. (1976). J. agric. Fd Chem. 24, 287.

Rolls, B. A., Hegde, S. N. \& Coates, M. E. (1976). Lab. Anim. 10, 291.

Somogyi, M. (1930). J. biol. Chem. 86, 655. 